\title{
Structure of the Cell Wall of Lactobacilli
}

\author{
ROLE OF MURAMIC ACID PHOSPHATE IN LACTOBACILLUS FERMENTI
}

\author{
By K. W. KNOX AND KLARA J. HOLMWOOD \\ Institute of Dental Research, United Dental Hospital, \\ Surry Hills, N.S.W. 2010, Australia
}

(Received 15 December 1967)

\begin{abstract}
1. The polysaccharide and mucopeptide components of the cell wall of Lactobacillus fermenti, serological group $\mathbf{F}$, were separated by mild conditions of acid hydrolysis; the polysaccharide was composed of glucose and galactose. 2. Soluble cell-wall products were isolated from cell wall lysed by lysozyme and a Streptomyces enzyme preparation. The lysozyme-dissolved fraction contained a greater proportion of mucopeptide. 3. The soluble preparations were heated in dilute acid to hydrolyse the linkage between the polysaccharide and mucopeptide components and then incubated with acid phosphatase. 4. Inorganic phosphate was released from products of Streptomyces enzyme action but not from products of lysozyme action. 5. The phosphate was shown to be present in the mucopeptide as muramic acid phosphate. It is concluded that in the intact wall polysaccharide is joined to muramic acid by a phosphodiester linkage.
\end{abstract}

Previous studies (Hall \& Knox, 1965; Knox \& Hall, 1965) provided evidence that the polysaccharide and mucopeptide components of the cell wall of Lactobacillus casei are joined by a phosphodiester linkage between the potential reducing group of the terminal residue of the polysaccharide and a hydroxyl group of a hexosamine residue in the mucopeptide. It seemed probable that the phosphorylated hexosamine was muramic acid, though insufficient material was available for identification. Ågren \& de Verdier (1958) had previously reported the isolation of muramic acid phosphate from whole cells of $L$. casei, and Liu \& Gotschlich (1963) had obtained evidence for its presence in the cell wall of the pneumococcus. Subsequent studies by Liu \& Gotschlich (1967) confirmed this conclusion, and further indicated that muramic acid phosphate served as a cross-link between the mucopeptide and cell-wall polysaccharide of pneumococcus and group A streptococci; muramic acid phosphate was also detected in hydrolysates of cell walls from a number of other species of Gram-positive (but not Gram-negative) organisms, suggesting that its structural function is to provide such a linkage.

The present paper describes further studies on the linkage between the cell-wall components of lactobacilli. Following the earlier work with $L$. casei, an investigation was undertaken with $L$. fermenti. The results suggest that the polysaccharide and mucopeptide components are joined through a phosphodiester linkage and that the phosphorylated component is muramic acid phosphate.

\section{MATERIALS AND METHODS}

Organisms. L. fermenti strain N.C.T.C. 6991 was obtained from the National Collection of Type Cultures, Colindale, London; this strain was employed by Sharpe (1955) in the serological classification of lactobacilli and belongs to serological group F (Sharpe \& Wheater, 1957). Strain F 275C, designated $L$. fermentum biotype IIb (Reuter), was kindly supplied by Dr M. Rogosa, National Institute for Dental Research, Bethesda, Md., U.S.A. Strains 77 and 126 were isolated from saliva and identified by $\mathrm{Mr} \mathrm{H}$. C. Spies of this Institute. Cells were grown at $37^{\circ}$ for 2 days in the medium described by de Man, Rogosa \& Sharpe (1960).

By using the procedures described by Sharpe (1955), it was concluded that strains 77 and 126 belong to serological group F. However, extracts of strain F 275C did not react with antiserum to strain N.C.T.C. 6991, nor did extracts of strain N.C.T.C. 6991 react with antisera to strain F 275C.

Enzymes. Egg-white lysozyme (grade B) (muramidase, EC 3.2.1.17) was purchased from California Corp. for Biochemical Research, Los Angeles, Calif., U.S.A.; wheatgerm acid phosphatase (EC 3.1.3.2) was obtained from Worthington Biochemical Corp., Freehold, N.J., U.S.A. The Streptomyces muralytic enzyme (impure) was prepared and used as described by Knox (1963).

Preparation of cell wall and soluble cell-wall polymers. Cell-wall fractions were prepared and digested with the Streptomyces muralytic enzyme as described by Knox \& Hall (1965). Addition of $\left(\mathrm{NH}_{4}\right)_{2} \mathrm{SO}_{4}$ to $70 \%$ saturation yielded a small amount of precipitate, which was removed (fraction S1). The supernatant solution was dialysed and 
freeze-dried (fraction S2). From previous studies (Knox, 1963) it was expected that fraction S2 would be a polysaccharide-mucopeptide complex.

M. Rogosa (personal communication) has reported that cells of $L$. fermenti are lysed by egg-white lysozyme. After preliminary experiments, a preparation of cell wall from strain N.C.T.C. $6991(2 \cdot 0 \mathrm{~g}$.) was suspended in distilled water $(200 \mathrm{ml}$.) and the $\mathrm{pH}$ adjusted to $6 \cdot 0$. Lysozyme (40 mg.) was added and the suspension incubated for $16 \mathrm{hr}$. at $37^{\circ}$. Cell-wall residue was removed by centrifuging at $10000 \mathrm{~g}$ for $20 \mathrm{~min}$. The opalescent supernatant solution was centrifuged at $198000 \mathrm{~g}$ for $1 \mathrm{hr}$. to yield a gelatinous pellet, which was freeze-dried (fraction Ll); the clear supernatant solution was dialysed and the indiffusible portion freezedried (fraction L2).

Column chromatography. Sephadex G-50 (fine grade) and G-75 (fine grade) (Pharmacia, Uppsala, Sweden) were employed. For the purification of fractions L2 and S2, a solution of the material (up to $500 \mathrm{mg}$.) in $0.1 \mathrm{~N}$-acetic acid was applied to a column $(90 \mathrm{~cm} . \times 2.5 \mathrm{~cm}$.) of Sephadex G-75 and eluted at $2^{\circ}$ with $0 \cdot 1 \mathrm{~N}$-acetic acid; $8 \mathrm{ml}$. fractions were collected and carbohydrate was determined on $10 \mu \mathrm{l}$. by the cysteine- $\mathrm{H}_{2} \mathrm{SO}_{4}$ reaction (Dische, 1953). The fractions containing appreciable amounts of carbohydrate were pooled, dialysed and freeze-dried. The respective products were designated fractions L3 and S3.

Analytical methods. Glucose, total hexose, total hexosamine, glucosamine, muramic acid, total nitrogen and total phosphorus were estimated by the methods previously described (Knox, 1963; Knox \& Brandsen, 1962). Galactose was determined by the modification of the galactose oxidase method employed by Roth, Segal \& Bertoli (1965).

Samples for the determination of total and inorganic phosphorus were prepared for analysis (Knox \& Hall, 1965), and phosphorus was then determined by the method of Chen, Toribara \& Warner (1956).

Action of phosphatase on cell-wall products. The presence of a phosphomonoester in cell-wall products was detected by a modification of the method employed by Knox \& Hall (1965); $500 \mu \mathrm{g}$. of material in $0.2 \mathrm{ml}$. of a neutral solution was incubated for $16 \mathrm{hr}$. at $37^{\circ}$ with wheat-germ acid phosphatase $(0.1 \mathrm{mg}$. in $0.2 \mathrm{ml}$. of $0.2 \mathrm{M}$-acetate buffer, pH 5.4). The reaction was stopped by the addition of $0.1 \mathrm{ml}$. of $50 \%(\mathrm{w} / \mathrm{v})$ trichloroacetic acid, and inorganic

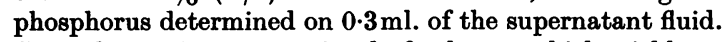
Control experiments consisted of tubes to which trichloroacetic acid was added before the enzyme, and tubes to which phosphate (up to $0.8 \mu \mathrm{g}$. of $\mathrm{P}$ in $0.1 \mathrm{ml}$.) was added, followed by trichloroacetic acid and enzyme.

It was observed by Knox \& Hall (1965) that the polysaccharide-mucopeptide complex from $L$. case $i$ caused a partial inhibition of the development of colour in the phosphorus estimation, e.g. $22 \%$ inhibition by $2.5 \mathrm{mg}$. Under similar conditions, fraction L3 gave $43 \%$ inhibition, whereas fraction S3 gave only $7 \%$ inhibition.

Wheat-germ acid phosphatase was also used for determining the relative amounts of phosphomonoester in column eluates of acid-hydrolysed material. The enzyme ( $0.1 \mathrm{mg}$.) in $0.1 \mathrm{ml}$. of $0.2 \mathrm{M}$-acetate buffer, $\mathrm{pH5} \cdot 4$, was added to $0.5 \mathrm{ml}$. of eluate and incubated at $37^{\circ}$ for $16 \mathrm{hr}$. Inorganic phosphorus was then determined.

Paper chromatography. Component carbohydrates were separated by chromatography in butan-1-ol-pyridine-water $\left(6: 4: 3\right.$, by vol.) and detected with alkaline $\mathrm{AgNO}_{3}$. The components of the mucopeptide were separated by twodimensional chromatography on Whatman no. 1 paper with butan-1-ol-acetic acid-water $(4: 1: 1$, by vol.) and pyridinewater $(4: 1, v / v)$ and detected with ninhydrin.

Paper electrophoresis. Hexosamines and hexosamine phosphates were separated by electrophoresis in pyridineacetic acid buffer, pH 6•3, on Whatman no. 3MM paper. A potential difference of $1000 \mathrm{v}$ was applied over a distance of $50 \mathrm{~cm}$. for 5-6hr. Hexosamines were detected with alkaline $\mathrm{AgNO}_{3}$ and ninhydrin, and phosphorus-containing compounds by the method of Hanes \& Isherwood (1949).

\section{RESULTS}

\section{Properties of cell-wall preparations}

Analyses. The presence of glucose and galactose as major components of the cell wall of the group $\mathbf{F}$ strains N.C.T.C. 6991,77 and 126 was indicated by paper chromatography and confirmed by determination with the specific enzymes D-glucose oxidase and D-galactose oxidase (Table 1); the cell wall of strain F275C contains very little hexose and presumably lacks cell-wall polysaccharide; on further investigation, a glycerol teichoic acid was shown to be present (A. J. Wicken \& K. W. Knox, unpublished work). Subsequent studies described herein are confined to strains N.C.T.C. 6991, 77 and 126.

Rate of release of polysaccharide by dilute acid. Previous studies with $L$. casei cell wall showed that the polysaccharide component was released on heating at $60^{\circ}$ in $0.1 \mathrm{~N}$-sulphuric acid (Knox \& Hall, 1965). Preparations of cell wall from strains N.C.T.C. 6991,77 and 126 ( $2 \mathrm{mg} . / 1.0 \mathrm{ml}$.) were heated under these conditions for periods up to $4 \mathrm{hr}$., and the amount of soluble carbohydrate was determined (Dische, 1953). In each case there was a rapid release similar to that previously described with $L$. casei: comparing the results for $2 \mathrm{hr}$. heating, the percentages of the total hexose released were $80 \%$ for $L$. case $i$ and $75 \%, 79 \%$ and $66 \%$ for L. fermenti strains N.C.T.C. 6991, 77 and 126. For each preparation complete release was achieved within $4 \mathrm{hr}$.

To detect the components of the soluble carbohydrate obtained from each strain of $L$. fermenti, the solutions were heated for $4 \mathrm{hr}$. at $100^{\circ}$ in $\mathrm{N}$-hydrochloric acid and subsequently examined by paper chromatography. Glucose and galactose were present in each hydrolysate; glucosamine was not detectable.

\section{Properties of soluble cell-wall products from strain N.C.T.C. 6991}

Products of lysozyme action. After the incubation of $2.0 \mathrm{~g}$. of cell walls with lysozyme (see the Materials and Methods section), the digest was centrifuged at $10000 \mathrm{~g}$ to remove a small amount of cell wall. 
Table 1. Composition of the cell wall and cell-wall fractions from strains of L. fermenti

Procedures for the preparation of the fractions are given in the text; 'mucopeptide' refers to the insoluble fraction remaining after acid extraction of wall. Results are expressed as a percentage of the dry weight of the fraction; total hexosamine is expressed as glucosamine.

\begin{tabular}{|c|c|c|c|c|c|c|}
\hline Strain & Fraction & $\begin{array}{c}\text { Total } \\
\text { nitrogen }\end{array}$ & Phosphorus & $\begin{array}{c}\text { Total } \\
\text { hexosamine }\end{array}$ & Glucose & Galactose \\
\hline F 275C & Wall & $10 \cdot 2$ & $4 \cdot 0$ & $17 \cdot 9$ & $1 \cdot 4$ & $6 \cdot 9$ \\
\hline 77 & Wall & $6 \cdot 5$ & $1 \cdot 4$ & $12 \cdot 3$ & $12 \cdot 9$ & $25 \cdot 6$ \\
\hline 126 & Wall & $6 \cdot 9$ & $0 \cdot 73$ & $12 \cdot 7$ & $18 \cdot 8$ & $25 \cdot 9$ \\
\hline N.C.T.C. 6991 & $\begin{array}{l}\text { Wall } \\
\text { S3 } \\
\text { L1 } \\
\text { L3 } \\
\text { Mucopeptide } \\
\text { Polysaccharide }\end{array}$ & $\begin{array}{c}7 \cdot 2 \\
1 \cdot 85 \\
6 \cdot 3 \\
6 \cdot 2 \\
12 \cdot 9 \\
2 \cdot 0\end{array}$ & $\begin{array}{l}0.20 \\
0.21 \\
0 \cdot 16 \\
0 \cdot 16 \\
0.34 \\
0.06\end{array}$ & \begin{tabular}{r|}
$17 \cdot 9$ \\
$5 \cdot 4$ \\
$18 \cdot 5$ \\
$15 \cdot 5$ \\
$33 \cdot 8$ \\
$1 \cdot 4$
\end{tabular} & $\begin{array}{c}20 \cdot 7 \\
30 \cdot 4 \\
21 \cdot 7 \\
21 \cdot 0 \\
1 \\
36 \cdot 3\end{array}$ & $\begin{array}{l}31 \cdot 5 \\
56 \cdot 8 \\
32 \cdot 8 \\
36 \cdot 0 \\
46 \cdot 5\end{array}$ \\
\hline
\end{tabular}

This residue was discarded and the supernatant solution centrifuged at $198000 \mathrm{~g}$ for $2 \mathrm{hr}$. The gel, which was deposited, was retained (fraction L1, $770 \mathrm{mg}$.), and the supernatant solution was dialysed. The yield of indiffusible material was $760 \mathrm{mg}$. (fraction L2); fractions L1 and L2 thus account for nearly $80 \%$ of the starting material.

Fraction L2 showed absorption in the ultraviolet with a plateau extending from 255 to $275 \mathrm{~m} \mu$. Chromatography on Sephadex G-75 removed the contaminating material (which would have included lysozyme) to give a fraction designated L3. Analyses of fractions $\mathrm{Ll}$ and L3, given in Table 1, indicate that each fraction is a polysaccharidemucopeptide complex similar in composition to the whole cell wall. It is presumed that they differ only in molecular weight, representing the result of variations in the degree of depolymerization achieved by lysozyme.

Products of Streptomyces enzyme action. From $2 \mathrm{~g}$. of cell walls, the yield of soluble indiffusible material was $1 \cdot 39 \mathrm{~g}$. The material (fraction S2) had an absorption maximum in the ultraviolet at $260 \mathrm{~m} \mu$. Chromatography of fraction S2 on Sephadex G-75 removed the contaminating material to give a fraction designated S3. Fraction S3 differs from fraction L3 (obtained by lysozyme action) in containing less hexosamine and therefore less mucopeptide. Incubation of fraction L3 with Streptomyces enzyme, followed by ammonium sulphate fractionation, decreased the total nitrogen from $6.2 \%$ to $1.9 \%$, and the hexosamine content from $18.5 \%$ to $6.3 \%$, with a corresponding increase in the total hexose from $\mathbf{3 3 . 5} \%$ to $\mathbf{5 5 \%}$ (fraction L3S).

Preparation of cell-wall polysaccharide. Cell wall $\left(2.0 \mathrm{~g}\right.$.) was heated for $20 \mathrm{~min}$. at $60^{\circ}$ in $200 \mathrm{ml}$. of $0 \cdot 1 \mathrm{~N}$-sulphuric acid with stirring. After cooling, the suspension was centrifuged and the supernatant removed. The residue was suspended in acid and heated as before. This procedure was repeated to yield six soluble fractions, which were pooled and dialysed. From carbohydrate determinations it was concluded that $97.8 \%$ of the polysaccharide was indiffusible (cf. Hall \& Knox, 1965). The yield of material after freeze-drying was $350 \mathrm{mg}$.

Analyses, given in Table 1, confirm that the preparation is predominantly polysaccharide; chromatography after acid hydrolyses (6N-hydrochloric acid at $100^{\circ}$ for $5 \mathrm{hr}$.) indicated that a protein contaminant probably accounted for the relatively high total nitrogen content.

The residue remaining after the above procedure was heated for $16 \mathrm{hr}$. at $60^{\circ}$ in $0 \cdot 1 \mathrm{~N}$-sulphuric acid, washed and freeze-dried. Qualitative analyses by two-dimensional chromatography showed the expected mucopeptide components: glucosamine, muramic acid, aspartic acid, lysine and alanine.

To compare the relative molecular weights of fractions L3 and S3 and the cell-wall polysaccharide, $25 \mathrm{mg}$. of material was eluted with $0 \cdot 1 \mathrm{~N}$ acetic acid from a column $(90 \mathrm{~cm} . \times 1.5 \mathrm{~cm}$.) of Sephadex G-75; $5 \mathrm{ml}$. fractions were collected and carbohydrate was determined on $0.1 \mathrm{ml}$. samples. Fraction L3 was eluted in the void volume, the maximum amount of carbohydrate being in tube 10 . The maximum amounts of fraction S3 and polysaccharide were contained in tubes 16 and 18 respectively. For comparison, the polysaccharide from $L$. casei N.I.R.D. R 094, which has a molecular weight of 11500-12500 (Hall \& Knox, 1965), was eluted from the same column; the maximum amount appeared in tube 17.

Action of phosphatase on soluble cell-wall products. The purified fractions obtained after the action of lysozyme (fraction L3) and Streptomyces enzyme (fraction S3) contained $0.16 \%$ and $0.21 \%$ of organic phosphorus respectively. By using the procedures 
Table 2. Action of phosphatase on preparations of polysaccharide-mucopeptide complex

Preparations S3, L3 and L3S were hydrolysed for $40 \mathrm{~min}$. and $3 \mathrm{hr}$. at $60^{\circ}$ in $0 \cdot 1 \mathrm{~N}-\mathrm{H}_{2} \mathrm{SO}_{4}$ and subsequently incubated with wheat-germ acid phosphatase. The percentage of the total phosphorus released by enzyme was then calculated.

$\begin{array}{cccc}\text { Preparation } & \begin{array}{c}\text { Total } \\ \text { phosphorus } \\ (\%)\end{array} & \overbrace{\begin{array}{c}\text { Hydrolysed } \\ \text { for 40min. }\end{array}}^{\text {by enzyme (\% of total) }} & \begin{array}{c}\text { Hydrolysed } \\ \text { for } 3 \mathrm{hr} .\end{array} \\ \text { S3 } & 0 \cdot 21 & 22 & 42 \\ \text { L3 } & 0 \cdot 16 & - & 2 \\ \text { L3S } & 0 \cdot 21 & - & 58\end{array}$

employed previously with fractions from $L$. casei (Knox \& Hall, 1965), evidence was sought that the potential reducing end group of the polysaccharide is joined to the mucopeptide through an orthophosphate group. Preliminary experiments indicated that acid phosphatase did not liberate detectable amounts of inorganic phosphate unless there had been prior acid hydrolysis $(0 \cdot 1 \mathrm{~N}$-sulphuric acid at $60^{\circ}$ ) of the polysaccharide-mucopeptide complex. The periods of acid hydrolysis chosen were $40 \mathrm{~min}$. and $3 \mathrm{hr}$. at $60^{\circ}$ in $0.1 \mathrm{~N}$-sulphuric acid; with cell-wall preparation $46 \%$ of the total hexose was released in $40 \mathrm{~min}$. and $95 \%$ in $3 \mathrm{hr}$.

Solutions $(0.5 \%)$ of fractions L3 and L3S in $0 \cdot 1 \mathrm{~N}$-sulphuric acid were heated at $60^{\circ}$ for $3 \mathrm{hr}$. and of fraction S3 for $40 \mathrm{~min}$. and $3 \mathrm{hr}$.; phosphomonoester was then determined (see the Materials and Methods section). The results (Table 2) showed that inorganic phosphate was released from hydrolysed fractions S3 and L3S, but not from hydrolysed fraction L3. The mucopeptide component of fraction S3 (see below) was also examined for the action of wheat-germ acid phosphatase; this preparation contains $1.05 \%$ of organic phosphorus and $58 \%$ of this was released by the enzyme.

\section{Phosphorylated component of the mucopeptide}

Isolation of mucopeptide from fraction S3. Fraction S3 (100 mg.) was heated in 0.1 N-sulphuric acid $\left(10 \mathrm{ml}\right.$.) at $60^{\circ}$ for $2 \mathrm{hr}$. The solution was neutralized, concentrated, applied to a column $(90 \mathrm{~cm} . \times 1.5 \mathrm{~cm}$.) of Sephadex G-50 and eluted with water. Fractions (5 ml.) were collected and assayed for carbohydrate $(10 \mu \mathrm{l}$.) and phosphomonoester $(0.5 \mathrm{ml}$.). The results indicated that fractions containing phosphomonoester (tubes 17-21) were associated with mucopeptide without carbohydrate attached, and could be effectively separated from the polysaccharide component and any unhydrolysed complex (tubes 11-14). Subsequently, 500 mg. of material was hydrolysed and applied in three equal portions to the column. The fractions containing phosphomonoester (i.e. free mucopeptide), but only trace amounts of carbohydrate, were pooled and freeze-dried. The yield was $45 \mathrm{mg}$.

Identification of muramic acid phosphate. The components of the mucopeptide, identified by paper chromatography, wore glucosamine, muramic acid, glutamic acid, aspartic acid, lysine and alanine.

For the detection of the phosphorylated component, mucopeptide (10mg.) was hydrolysed in $6 \mathrm{~N}$-hydrochloric acid for $6 \mathrm{hr}$. at $100^{\circ}$. After repeated evaporation to dryness in vacuo the hydrolysate was examined by paper electrophoresis. In addition to components with mobilities identical with those for muramic acid and glucosamine, there was an amino sugar migrating towards the anode that gave a positive reaction for phosphorus.

The remainder of the hydrolysate was applied as a band to a sheet of Whatman no. 3MM paper. After paper electrophoresis guide strips were stained to detect the phosphorylated amino sugar and the corresponding strip was cut out and eluted. A portion of the eluate was incubated with wheatgerm acid phosphatase under the same conditions as used previously; the products of enzyme action were inorganic phosphate and a hexosamine that was indistinguishable from muramic acid on electrophoresis and chromatography. In the Elson-Morgan hexosamine reaction, the eluate gave an absorption curve identical with that for muramic acid, the maximum being at $510 \mathrm{~m} \mu$. The molar ratio of phosphorus to muramic acid was $0.91: 1.00$.

L. casei mucopeptide. The phosphorylated hexosamine present in acid hydrolysates of the mucopeptide from $L$. casei (Hall \& Knox, 1965) was indistinguishable on electrophoresis from muramic acid phosphate isolated from $L$. fermenti.

\section{DISCUSSION}

The presence of muramic acid phosphate as a component of the cell wall of Gram-positive bacteria has been well documented. After acid hydrolysis the phosphate is attached to position 6 of muramic acid (Button, Archibald \& Baddiley, 1966; Heymann, Manniello \& Barkulis, 1967 ; Liu \& Gotschlich, 1967), though the possibility of phosphoryl migration from position 4 has not been excluded (cf. Button et al. 1966; Heymann et al. 1967). Attached to the mucopeptide of most, if not all, Gram-positive bacteria are specific polymers, some of which, including the teichoic acids, contain phosphorus. In several instances there is suggestive evidence that these phosphorus-containing polymers are joined to the mucopeptide through a phosphodiester linkage (Strominger \& Ghuysen, 
1963; Ghuysen, Tipper \& Strominger, 1965), and that the linkage involves muramic acid (Button et al. 1966; Heymann et al. 1967; Liu \& Gotschlich, 1967).

The cell walls of a number of Gram-positive organisms that lack teichoic acid and related polymers still contain a significant amount of phosphorus (Archibald, Armstrong, Baddiley \& Hay, 1961), and it seems likely that this is accounted for, at least in part, by muramic acid phosphate (Liu \& Gotschlich, 1967; Montague \& Moulds, 1967). In two instances there is suggestive evidence for a phosphodiester linkage between the polysaccharide and mucopeptide (Hall \& Knox, 1965; Knox \& Hall, 1965; Liu \& Gotschlich, 1967), though Hall \& Knox (1965), working with L. casei, did not identify the phosphorylated hexosamine. The results of the present study have confirmed that the phosphorylated hexosamine in $L$. casei is muramic acid, and have also provided evidence for its occurrence in L. fermenti.

Cummins \& Harris (1956) and Ikawa \& Snell (1960) showed the presence of glucose, galactose, glucosamine, muramic acid, glutamic acid, aspartic acid, lysine and alanine in the cell wall of $L$. fermenti. The present studies indicate that these analyses apply to strains in serological group $F$, and further show that glucose and galactose but not glucosamine are the components of the cell-wall polysacccharide. The report of Sharpe, Davison \& Baddiley (1964) provided preliminary evidence that group $\mathrm{F}$ specificity probably depended on an intracellular teichoic acid, and studies with strains N.C.T.C. 6991,77 and 126 have confirmed this (K. W. Knox \& A. J. Wicken, unpublished work).

A comparison of the results obtained with $L$. casei and $L$. fermenti indicates that each contains a polysaccharide component accounting for about two-thirds of the weight of the isolated wall preparation, with the molecular weights of the polysaccharide units being very similar. However, only the cell wall of $L$. ferment $i$ is lysed by lysozyme. The cell-wall polysaccharide of this species lacks glucosamine, whereas glucosamine is a component of the polysaccharide from $L$. casei. A number of factors influence lysozyme action (Perkins, 1967; Work, 1967), but, as $N$-acetylglucosamine and certain derivatives are inhibitory (Neuberger \& Wilson, 1967; Sharon, 1967), it is feasible that the presence of $N$-acetylglucosamine in the cell-wall polysaccharide may contribute to the observed differences in susceptibility to lysozyme. The results of Brumfitt (1959) with cell-wall teichoic acids may be interpreted to support this suggestion: it was found that Staphylococcus aureus, which possesses a teichoic acid containing $N$-acetylglucosamine, was resistant to lysozyme (even after the removal of $O$-acetyl groups), whereas Bacillus subtilis, which possesses a teichoic acid containing glucose, is lysozyme-sensitive.

Previous studies with $L$. casei had shown that the polysaccharide component was completely released from the cell wall under mild conditions of acid hydrolysis with the concomitant appearance of an orthophosphate susceptible to the action of wheatgerm acid phosphatase (Knox \& Hall, 1965). Similar results have now been obtained with $L$. fermenti. The ability to detect the orthophosphate component of the mucopeptide from $L$. fermenti depended on the mode of preparation of the substrate: the phosphatase had no detectable action on the mucopeptide component resulting from the action of the lysozyme, but did act on the mucopeptide component resulting from the action of the crude Streptomyces enzyme. As indicated by chemical analysis and column chromatography, the products of lysozyme action contained relatively more mucopeptide than did the products of Streptomyces action, suggesting that the action of wheat-germ acid phosphatase is influenced by the size of the mucopeptide component. This is supported by the finding that further digestion of the lysozyme-soluble products with the Streptomyces enzyme rendered the mucopeptide susceptible to the subsequent action of acid phosphatase. The relative amount of mucopeptide in the cell-wall preparations also influenced the detection of inorganic phosphorus, the mucopeptide inhibiting the determination by up to $43 \%$. Evidence reported here and elsewhere for the presence of a phosphodiester linking the cell-wall components is indirect, depending on the enzymic detection of an orthophosphate grouping in the products of acid hydrolysis; the results with $L$. fermenti indicate that such an orthophosphate grouping, though present, may not be detectable.

This work was supported by a grant from the National Health and Medical Research Council of Australia.

\section{REFERENCES}

Ågren, G. \& de Verdier, C.-H. (1958). Acta chem. scand. $12,1927$.

Archibald, A. R., Armstrong, J. J., Baddiley, J. \& Hay, J. B. (1961). Nature, Lond., 191, 570.

Button, D., Archibald, A. R. \& Baddiley, J. (1966). Biochem. J. 99, $11 \mathrm{c}$.

Brumfitt, W. (1959). Brit.J.exp. Path.40,441.

Chen, P. S., Toribara, T. Y. \& Warner, H. (1956). Analyt. Chem. 28, 1756.

Cummins, C. S. \& Harris, H. (1956). J. gen. Microbiol. 14, 583.

de Man, J. C., Rogosa, M. \& Sharpe, M. E. (1960). J.appl. Bact. 23, 130.

Dische, Z. (1953). J. biol. Chem. 204, 983.

Ghuysen, J.-M., Tipper, D. J. \& Strominger, J. L. (1965). Biochemistry, 4, 474.

Hall, E. A. \& Knox, K. W. (1965). Biochem. J. 96, 310. 
Hanes, C. S. \& Isherwood, F. A. (1949). Nature, Lond., 164, Neuberger, A. \& Wilson, B. M. (1967). Nature, Lond., 215, 1107. 524.

Heymann, H., Manniello, J. M. \& Barkulis, S. S. (1967). Biochem. biophys. Res. Commun. 26, 486.

Ikawa, M. \& Snell, E. E. (1960). J. biol. Chem. 235, 1376.

Knox, K. W. (1963). J. gen. Microbiol. 31, 59.

Knox, K. W. \& Brandsen, J. (1962). Biochem. J. 85, 15.

Knox, K. W. \& Hall, E. A. (1965). Biochem. J. 94, 525.

Liu, T.-Y. \& Gotschlich, E. C. (1963). J. biol. Chem. 238, 1928.

Liu, T.-Y. \& Gotschlich, E. C. (1967). J. biol. Chem. 242, 471.

Montague, M. D. \& Moulds, J. D. (1967). Biochim. biophys. Acta, 135, 565.

Perkins, H. R. (1967). Proc. Roy. Soc. B, 107, 443.

Roth, H., Segal, S. \& Bertoli, D. (1965). Analyt. Biochem. 10, 32.

Sharon, N. (1967). Proc. Roy. Soc. B, 167, 402.

Sharpe, M. E. (1955). J. gen. Microbiol. $12,107$.

Sharpe, M. E., Davison, A. L. \& Baddiley, J. (1964). J. gen. Microbiol. 34, 333.

Sharpe, M. E. \& Wheater, D. M. (1957). J. gen. Microbiol. 16, 676.

Strominger, J. L. \& Ghuysen, J.-M. (1963). Biochem. biophys. Res. Commun. 12, 418.

Work, E. (1967). Proc. Roy. Soc. B, 167, 446. 